\title{
Accuracy of Estimating Compressive Strength of Deteriorated Concrete Seawall by Nondestructive Evaluation (NDE)
}

by A. Michel Alexander

U.S. Army Corps of Engineers

Waterways Experiment Station

3909 Halls Ferry Road

Vicksburg, MS 39180-6199

Final report

Approved for public release; distribution is unlimited

\footnotetext{
Prepared for U.S. Army Corps of Engineers

Washington, DC 20314-1000

Under Work Unit 32638
} 